\title{
Dulce et Utile: A Pedagogical Inquiry into Rumi's Story of The Lion and the Beasts of Chase
}

\author{
Hossein Fathi Pishosta
}

Member of the Academic Board of Rafsanjan Vali-e-Asr University, Rafsanjan, Kerman (Iran)

Corresponding author: fathi.hoss@gmail.com

\section{Doi:10.5901/mjss.2015.v6n6s1p254}

\section{Abstract}

Rumi's opus magnum or 'great work' the Mathnawi provides readers with a fine example of the sugar-coated formula proposed by the leading Roman poet, Horace: "dulce et utile": Poetry should simultaneously teach and delight the reader. The pedagogical dimension of Rumi's work has not been much addressed by scholars and researchers; hence this study addresses the issue by drawing on the story of The lion and the Beasts of Chase from the Mathnawi. It highlights the contribution of several artistic and narrative elements to the pedagogical appeal of Rumi's masterpiece and their educational implications for both teachers and learners. Rumi's use of narrative techniques such as the story-within-story or the frame-story technique, allegory, symbolism, repartee and the principle of bi-polarity, allusion, repetition, and concentration or epigrammatic quality in the story suggest that he not only highlights the content of education but also the form of education; it is, indeed, the form or framework of the Mathnawi and the poet's teaching methodology that makes it a landmark text for readers. Although the artistic unity of the work has been the subject of much critical controversy, nevertheless, this study argues for the work's organic unity at both semantic and structural levels. A pedagogical inquiry into Rumi's work delineates the universal charm of his art and makes the case for taking into account questions of delightful teaching.

Keywords: Pedagogical, Rumi, the Mathnawi, The lion and the Beasts of Chase

\section{Introduction}

Nowadays, the significance of pedagogical approaches is much highlighted in learning environments and teachers have access to a multiplicity of approaches so that learners develop a variety of options to construct their knowledge. Indeed, the effectiveness of learning depends to a great extent on the methodology based on which instructors present their educational content. Teaching strategies are used in varying ways in different disciplines. Like other disciplines, in teaching literature learning is enhanced especially when learners are engaged in the learning process and are motivated to follow the whole process. This is the point that is best projected in the Mathnawi of the celebrated Persian poet and mystic Jalal-al-Din Rumi (1207-1273). The pedagogical aspect of Rumi's masterpiece Mathnawi has not been much the focus of critical attention; hence this study undertakes the issue and aims at elucidating the various teaching strategies employed by the poet in the work. This, in itself, paves the way for further studies in this regard.

As one of the world's greatest masterpieces of mystical literature, Rumi's Mathnawi depicts the main themes of Sufism and various facets of human life including the social, moral, humanistic, psychological, and philosophical dimensions. In doing so, Rumi makes use of stories which are of great pedagogical and artistic significance. The work, in deed, provides readers with a fine example of the maxim referred to by the much acclaimed Roman Poet Horace (65-8 $\mathrm{BC}$ ) in his Ars Poetica (Art of Poetry): dulce et utile; holding the poet in very high esteem, Horace observes that poetry should be both pleasing and useful (dulce et utile): "The man who combines pleasure with usefulness wins every suffrage, delighting the reader and also giving him advice" (p. 130). Discussions regarding the work's organization and structure have also proved to be a site of controversy among critics.

On the one hand a number of critics have referred to the poem's causal and rambling organization; according to Browne (1951) the Mathnawi:

Contains a great number of rambling anecdotes of the most various character, some sublime and dignified, others grotesque and even (to our ideas) disgusting, interspersed with mystical and theological digressions, often of the most abstruse character, in sharp contrast with the narrative portions, which, though presenting some peculiarities in diction, are as a rule couched in very simple and plain language. (p. 520) 
In the same vein, Chittick (1983) observes that the Mathnawi is "a rambling collection of anecdotes and tales derived from a great variety of sources, from the Qur'an to the folk humour of the day" (p. 6).

On the other hand, some critics have argued for the poem's structural unity. In this regard, Nicholson observes that: "Anyone who reads the poem attentively will observe that its structure is far from being as causal as it looks. To say that "the stories follow each other in no order" is entirely wrong: they are bound together by subtle links and transitions arising from the poet's development of his theme; and each Book forms an artistic whole" (as cited in Weightman, 2003, p. 12).

This study presents a pedagogical inquiry into the story of The lion and the Beasts of Chase from Rumi's Mathnawi. It investigates the contribution of several narrative and artistic elements to the educational appeal of the poem; finally, it presents an analysis of the work's structure and organization.

\section{The Pedagogical Appeal of the Mathnawi}

The pedagogical appeal of the Mathnawi is due to the functioning of several artistic and narrative elements employed by Rumi; among these elements is Rumi's use of the frame-story or the story-within-story technique. The poet embeds within some main narratives other stories and anecdotes; these secondary stories not only have their own integrity and unity, but they also function as a chain in the whole narrative. This method of storytelling is to some extent similar to the procedure employed in The Thousand and One Nights. Geoffrey Chaucer in his Canterbury Tales and Boccaccio in his Decamron, also employ somewhat similar narrative techniques. In this regard, Jamalzadeh (1957) mentions that the majority of stories remind one of a tree that from its trunk many branches grow (P. 13). That is, the Mathnawi is like a tree and the narratives constitute its branches. It is an organic structure and has the quality of livelihood and freshness. This method of narration as Jamalzadeh suggests can be called 'the circle within circle' technique. When a drop of rain falls in a pool, a circle is formed, then within the same circle many other circles are formed (ibid.). Each circle is a separate narrative, has its own roundness and completeness and simultaneously functions as a link within the whole poem. The story of The lion and the Beasts of Chase is a good example of the case; it opens when the poet in the last line of the previous narrative mentions:

Seek the story (illustrating this) from the book of Kalila (and Dimna), and search out the moral (contained) in the story. (M I, 899)

The pedagogical appeal of Rumi's work also manifests itself in his use of allegory. Various literary genres can be classified as types of allegory, in that they all narrate though in varied forms "one coherent set of circumstances which are intended to signify a second order of correlated meanings" (Abrams \& Harpham, 2005, P. 7). The significance of Rumi's work is due to the fact that while he is narrating a simple tale, at the same time the subtlest mystical subjects as well as different aspects of everyday life are very beautifully portrayed. According to A.J. Arberry (1961) the material which makes up the Mathnawi can be divided into two different though by no means distinct categories: "theoretical discussion of principal themes of Sufi's mystical life and doctrine, and stories or fables intended to illustrate those themes as they arise" (P. II).

One type of allegory is the beast fable; some stories in the Mathnawi such as The lion, The Wolf and the Fox, The Falcon and the Owls, The Mouse and the Camel are beast fables in which certain animals talk and act like the human beings of which they are representatives and Rumi through them brings home for the reader his didactic teachings. These stories are so pregnant with meaning that one can read them at several levels. The story of The Lion and the Beasts of Chase is about a group of animals who are chased and harassed by a lion in a lush valley. The narrative can be read at least at two levels. As a pure tale or story of incident the focus of the story is on the course and the outcome of the events; a group of animals being in trouble by a lion contrive a plan against him and finally bring his downfall through the scheming of a hare which lures the lion into a well. At this level the story becomes entertainment; however the aim of Rumi's narrative is not mere story-telling; the poem has some idea or theme beyond its artistic and well-wrought framework that is of central significance. It can be read as an allegory of the obstacles that a wayfarer or even a common person faces in the valley of life. It is a parable and poses a dilemma for everyone, that is, how can one solve some problems and achieve his /her goals.

In addition to allegory, symbolism is one of the main aspects of Rumi's narratives. A literary symbol is defined as "a word or phrase that signifies an object or event which in its turn signifies something, or suggests a range of reference beyond itself" (Abrams \& Harpham, 2005, p. 320). Symbols are highly suggestive and enjoy a higher mode of artistic expression; they may be "public or private, universal or local" (Cuddon, 1999, p. 885). Rumi's symbolism is universal and 
transcends its geographical boundaries. The story of The Lion and the Beasts of Chase is highly symbolic. The climax of the story comes when the lion accepts the daily ration that beasts of the symbolic valley propose him provided that he no longer should hide in ambush and spring on and kill them. This submission to the will of animals proves as his tragic flaw and brings about his final downfall. The hare, a symbol of wisdom in the story, tricks the lion to jump into the symbolic well. What is interesting about Rumi's narrative is that even at the level of symbolism the story takes divergent dimensions. On the one hand, the lion may be regarded as the symbol of the spirit (ruh) which is infected by the beasts representing the Nafs or the flesh and hence the lion is finally defeated; at the beginning of the story, the lion says that:

I'm done to death by the cunning and fraud of men, I am beaten by the sting of ( human) snake and scorpion;

But worth than all men in fraud and spite is the man of the flesh (nafs) lying in wait within me.

(M I, 905-906)

On the other hand, the animals represent the spirit (ruh) which is invaded by the Nafs, the epitome of which is the lion. Here it is a question of reading; Joseph (1997) suggests that since the final victory is achieved by the beasts, the second interpretation seems more likely (pp.13-14), but it still remains problematic. This illustrates the depth of Rumi's symbolism. In the story of The Merchant and the Parrot, Rumi mentions that:

When I speak of "lip", it's the lip (shore) of the Sea; when I Say "not" the intended meaning is "except". (MI, 1759)

Repartee or verbal fencing is another artistic element in Rumi's Mathnawi which enhances its pedagogical delight. The poet usually puts forward two opposing attitudes or themes side by side and addresses the debate from different perspectives; Although often one attitude dominates at the end, but in some cases the result is what the English romantic poet Samuel Taylor Coleridge (2006) calls "the balance or reconciliation of opposite or discordant qualities" (P. 482); that is both attitudes are reasonable and can be justified; the result is similar to what Samuel Johnsons (2009) in his Lives of the Poets defines as discordia concors (harmonious discord) in which opposites are juxtaposed so that the contrast between them is striking: "a combination of dissimilar images, or discovery of occult resemblances in things apparently unlike" (p.398). This is also in line with William Blake's (2006) belief in the union or marriage of the contraries; As he observes, "without contraries [there] is no progression" (p.110). The main focus of the story of The lion and the Beasts of Chase is on a series of dialogues between the lion favoring Jahd (exertion), acquisition or work and the beasts preferring Tavakol (trust in God), resignation and Destiny. Each group sets forth their ideas fully and convincingly. Rumi's dialectics, indeed, is based on reasonable argument. Although the lion is finally defeated, however his argument is not totally wrong; what the lion says is also very logical and supportable. In other words, both Jahd (exertion) and Tavakol (trusting in God) are necessary for the wayfarer and does not contradict each other. In this regard, Ziai (1971) mentions that: "there is a prevalent concept in Rumi's Mathnawi that all things come to be known by their opposites"; he calls this the Principle of bi-polarity of all things in the Mathnawi (P.63). In putting forth their ideas each group draws on a wide range of religious, literary and cultural sources and Rumi's language becomes highly allusive.

Allusion is another artistic element that is widely employed in Rumi's Mathnawi and accounts for its pedagogical appeal. Rumi's use of allusion is in line with T. S. Eliot's (2006) maxim that the "poet must become more and more comprehensive, more allusive, more indirect, in order to force, to dislocate if necessary, language into his meaning" ( $p$. 2330). In the Mathnawi one finds references to the tenets of earlier Sufism, besides the innumerable hidden and overt allusions to the words of Quran and to the prophetic tradition. In the story of The lion and the Beasts of Chase to support Jahd (exertion) and Tavakol (trusting in God) each side of the debate makes use of a language that is infused with images from the very sphere of daily life as well as allusions to the religious tradition. Each group conducts his argument with several allusions which repeat the same idea but in a new form.

Repetition of ideas, images, words and phrases, is also another narrative element that is employed artistically in Rumi's work. This technique has been frequently used in religious texts and also in oral poetry; many sermons and religious works make extensive use of this technique for preaching and didactic purposes. Homer, in his lliad and Odyssey, and the Beowulf poet are familiar with the practice of oral poetry and employ oral techniques such as the repetition of stock words and phrases. Lodge (2002) regards this principle as an aspect of the function of language in literary texts; he states that: "the perception of repetition is the first step towards offering an account of the way language works in extended literary texts, such as novels" (P. 86). In some narratives Rumi mentions several examples about the same topic; this sort of repetition is not however boring and tedious because each repetition being highly allusive and meaningful looks at the same topic from a different perspective; hence repetition turns into variety and freshness. In some cases a word or phrase diverts the poet from the main process of narration and is discussed at full length. The narrative 
of The Lion and the Beasts of the Chase is a good example of the case. In proving the preference of Tavakole (trust in God) over Jahd (exertion) or vice versa, the poet brings several arguments supporting the same idea. Rumi does this consciously and loses no opportunity for teaching. The use of repetition technique is not in conflict with the technique of concentration in Rumi's narratives.

Concentration or epigrammatic quality is one of the main narrative techniques that Rumi employs in his work and enjoys pedagogical consideration. At the beginning of the Mathnavi, Rumi expresses his theme of themes; in The lament of the Reed-Flute he mentions that:

I want a bosom torn by severance that I may unfold (to such a one) the pain of love-desire. $(M I, 3)$

The whole Mathnawi can be read as an expression of the poet's pain of love-desire; the beginning eighteen lines of this lament are, indeed, the epitome of Rumi's entire masterpiece. Many narratives in the Mathnawi have epigrammatic quality; Abrams (2005) defines epigram as a term that is: "used for a statement, whether in verse or prose, which is terse, pointed, and witty. The epigram may be on any subject and in any mode, amatory, elegiac, meditative, complimentary, anecdotal, or (most often) satiric"(p. 84). In Rumi's poem many lines are compressed with meaning; the concluding lines of most narratives are best examples of the epigrammatic quality and the concentration of meaning. The final lines of the story of The Lion and the Beasts of the Chase are also epigrammatic; after the fall of the lion into the well by the trickery of the hare, the poet concludes that:

O thou lion that liest at the bottom of this lonely well, thy hare-like soul (nafs) has shed and drunk thy blood. ( $M I, 1351)$

In another part of the narrative, the poet once more concludes that:

O kings, we have slain the outward enemy, (but) there Remains within (us) a worth enemy than he,

To slay this (enemy) is not the work of reason and intelligence

The inward lion is not subdued by the hare.

(M I, 1372-1373)

The 'epigrammatic ending' of most narratives is very interesting; after mentioning a narrative which seems pure story, Rumi in some cases in the final lines, very artistically summarizes the whole idea behind the narrative. The story of The Elephant in the Dark is a good instance of this technique. Al-GHazali in Revival of Religious Sciences, and also Sana'i in his Garden (Hadighat-al-Haghigha) tell the anecdote in considerable length, but Rumi reveals the the same narrative very briefly; a short account of the story is that: some Hindus brought an elephant for exhibition and placed it in a dark place, many people went to visit it; since it was dark, each visitor felt it with the palm of his hand and he/she had a different interpretation of the appearance of the beast. Rumi, after telling his narrative summarizes the lesson of the story in the final two lines:

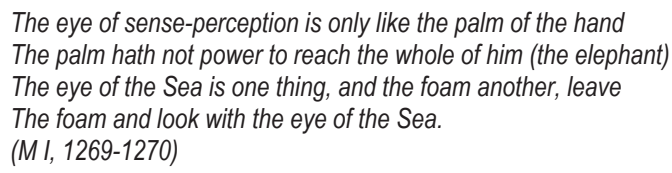

\section{Conclusion}

The pedagogical appeal of Rumi's masterpiece, the Mathnawi, is a subject that has not been much addressed by researchers; the work finds its pedagogical and educational resonance due to the functioning of several artistic elements. Rumi's use of narrative techniques such as the frame-story technique, allegory, symbolism, repartee and the principle of bi-polarity, allusion, repetition, and concentration or epigrammatic quality in the story of The Lion and Beasts of Chase all highlight the pedagogical dimensions of his work and its efficacy for educational purposes. Rumi, not only highlights the content of education but also pays great attention to the form of education; it is, indeed, the form or framework of the Mathnawi and the poet's teaching methodology that makes it a landmark text for readers and has influenced the thinking and orientation of a wide range of teachers and scholars. Although on the surface the whole work seems without any firm framework; however a common thread knits together the seemingly random and disjointed narratives; The sort of unity employed in the Mathnawi is, indeed, an organic one and has dynamic quality; it is observed through the whole poem and 
has primarily two aspects: first, it is the unity of idea or theme; the lessons that Rumi tries to bring home for the reader, or his teaching materials from the very beginning to the end are highly related to each other. The other element that gives the work its unity and was the focus of this study is the similar methodology or common narrative elements employed by Rumi in his narration of stories. Whatever the didactic function of Rumi's stories, it should not blind one to the artistic and pedagogical appeal of his work with its entertaining and charming theory of instruction. The poet's account of the lion and the beasts of chase makes the case for taking into account questions of delightful education and the way a work of art may inspire both learners and teachers.

\section{Works Cited}

Abrams, M. H., \& Harpham, G. G. (2005). A Glossary of Literary Terms. Boston: Thomson Wadsworth.

Arberry, A. J. (1961). Tales From Mathnavi. London: George Allen \& Unwin LTD.

Blake, W. (2006). The Marriage of Heaven and Hell. In The Norton Anthology of English Literature, eighth edition,vol. 2. Eds. M. H. Abrams and et all (pp. 110-120). New York, London: W. W . NORTON \& COMPANY.

Browne, E. G. (1951). A Literary History of Persia, Vol. Il. Cambridge: Cambridge University Press.

Chittick, W. c. (1983). The Sufi Path of Love. Albany: SUNY Press.

Coleridge, S. T. (2006). B iographia Literaria. In The Norton Anthology of English Literature,eights edition, Vol. 2. Eds. M. H. Abrams and et all. (pp. 474-484). New York, London: W. W . NORTON \& COMPANY .

Cuddon, J. A. (1999). Dictionary of Literary Terms \& Literary Theory. London: Penguine Reference.

Eliot, T. S. (2006). The Metaphysical Poets. In The Norton Anthology of English Literature,eighth ed., vol. 2. Eds. M. H. Abrams and et all (pp. 2325-2332). New York, London: W.W. Norton \& Company.

Horace. (2011). Ars Poetica (Art of Poetry) trans. D. A. Russel. In The Norton Anthology of Theory and Criticism, Second Edition, Vincent B. Leitch General Editor. (pp. 122-132). New York, London: W. W. Norton \& Company.

Jamalzade, M. A. (1957). Bange Nai (Dastanhaye Mathnavi Ma'navi). Tehran: Anjoman Ketab.

Johnson, S. (2009). Lives of the Poets. In Samuel Johnson, Selected writings: A Tercentenary Celebration, ed. Peter Martin (pp. 397491). Cambridge, Massachusetts: Harvard University Press.

Joseph, E. (1997). Nakhjiran Va Tootian. Shiraz: Entesharate Navid.

Lodge, D. (2002). Language of Fiction. New York: Routledge.

Weightman, S. (2003). Structure and the Mathnawi. In Rumi's Thoughts, ed. Seyed G. Safavi (pp. 9-18). Tehran: Salman-Azadeh Publication.

Ziai, H. (1971). The Principle of Bi-Polarity of All Things in the Mathnavi of Jalal-al-Din Rumi. In Aspects of Mevlana. Ed. Shchimmel, Annemarie. Ankara: Guven Matbaasi. 